\title{
The Relationship of Financial Reports on Performance Accountability Education Office of Batu Bara Regency
}

\author{
Mariani Meri Lumban Gaul ${ }^{1, *}$ Nasirwa $^{2}$, Chandra Situmeang ${ }^{3}$, Din Oloan Sihotang ${ }^{4}$ \\ ${ }^{1}$ Postgraduate Accounting Study Program of Universitas Negeri Medan, North Sumatra, Indonesia \\ ${ }^{2,3}$ Postgraduate School Universitas Negeri Medan North Sumatra, Indonesia \\ ${ }^{4}$ STP St. Bonaventura Keuskupan Agung Medan North Sumatra, Indonesia \\ *Corresponding author. Email: merymarbun03@gmail.com
}

\begin{abstract}
Financial report used as a basis for decision making because it aims to present information about the financial position, budget realization, excess budget balances, cash flows, operating results, and changes in equity of an entity in a report that is useful for users in making and evaluating decisions regarding resource allocation. Local Government Financial Reports have to be reported timely and reliable manner because Government financial reports are a form of external accountability of Regional Heads to the public, investors, creditors, donor agencies, the press, and other parties with an interest in the report as a basis for making economic decisions, social, and politic. Therefore, this study conducted to test whether there is a relationship between financial reports on performance accountability at Education Office of Batu Bara Regency.
\end{abstract}

Keywords: financial statements, accountability, performance.

\section{INTRODUCTION}

In regulation of the Minister of Home Affairs Indonesia Republic Number 59 of 2007 concerning Regional Financial Management guidelines that financial reporting aims to present information on financial position, budget realization, excess budget balance, cash flow, operating results, and changes in equity of an entity a useful report. for users to make and evaluate decisions about resource allocation. The Government Financial Report is a form of external accountability, namely the accountability of the regional head to the public, investors, creditors, donor agencies, the press, and other parties with an interest in the report as a basis for making economic, social, and political decisions because the Financial Report is used as a basis for decision making, the Regional Government Financial Reports must be presented in a timely and reliable manner.

In addition, the Financial Statements also need to be equipped with adequate disclosures regarding information that can influence decisions [1]. In The Dictionary of Accounting defines accountability as the responsibility of individuals or sections/departments for the performance of a particular function. Accountability can be established or formulated by certain legal rules or agreements. The [2] author also states that accountability can be viewed from various perspectives. From an accounting perspective, the American Accounting Association states that the accountability of a government entity can be divided into four groups, namely accountability to: a) Financial resources, b) Compliance with laws and administrative policies, c) The efficiency and economy of an activity, and d) The results of government programs and activities are reflected in the achievement of objectives, benefits and effectiveness.

The management of local government that is accountable also cannot be separated from the local government budget. This is related to the impact of the budget on the accountability of local governments in providing services to the community. One of the characteristics of a budget is the clarity of budget targets. Therefore, this study was conducted to test whether there is a relationship between the influences of Financial Statements on Performance Accountability at the Education Office of Batu Bara Regency. In connection with the research study, the null hypothesis ( $\mathrm{H} 0)$ was set indicating that there was no influence between the independent variable and the dependent variable. While the alternative hypothesis $(\mathrm{Ha})$ shows the influence between the independent variable and the dependent variable. 


\section{THEORETICAL DESCRIPTION}

\subsection{Financial Statement}

The financial report according to [3] is a structured report on the financial position and transactions carried out by a reporting entity. The general objective of financial statements is to provide financial position information, budget realization, excess budget balances, cash flows, results of operations, and changes in equity of a reporting entity that is useful for users in making and allocation of resources evaluating decisions.

\subsection{Accountability}

Accountability according to [4] is the obligation of the trustee (agent) to provide accountability, present, report and disclose all activities and activities that are his responsibility to the principal who has the right and authority to demand such accountability. The absence of financial reports indicates weak accountability. Furthermore, the weak accountability indicates that the weak accountability indicates a weak system which in turn has an impact on the culture of systematic corruption. So to erode corruption, one way is to cultivate a culture of making financial reports properly and correctly. In carrying out accountability, local governments are obliged to provide information as a form of fulfilling public rights. The rights of the public include: 1) the right to know, 2) the right to be informed, and 3 ) the right to heard and listened. Local governments are required to not only carry out vertical accountability. That is reporting to superiors, but also carrying out horizontal accountability, namely reporting to the Regional People's Representative Council (DPRD) and community [4].

\subsection{Dimension of Accountability}

Regarding Performance Accountability, there are 4 dimensions based on [5], namely:

\subsubsection{Legality and regulatory accountability}

Legal accountability is related to compliance with other laws and regulations required by the organization, while honesty accountability is related to avoiding abuse of office, corruption and collusion. Legal accountability ensures the enforcement of the rule of law, while accountability ensures healthy organizational practices.

\subsubsection{Process accountability}

Accountability process procedures used in carrying out the task is good enough. This type of accountability can be realized through the provision of public services that are fast, responsive, and inexpensive.

\subsubsection{Program accountability}

Program accountability also means that the organization's program should be a quality program and support and support the strategy in achieving the organization's vision, mission, and goals. Public institutions must be responsible for the programs that have been made up to the implementation of the program. And in this dimension, stakeholders or parties who make and carry out these policies are required to be able to achieve the vision and mission that is the goal of the organization.

\subsubsection{Policy of accountability}

Public institutions should be able to account for the policies that have been determined by considering future impacts. In making a policy, it must be considered what the purpose of the policy is, why the policy was carried out.

In practice, one form of accountability implementation is regulated by Presidential Instruction No. 7/1999 on Performance Accountability of Government Agencies. This instruction instructs every government agency to issue a Performance Accountability Report (PAR) at the end of the year. PAR contains accountability for activities in order to achieve the vision and mission of the organization [6].

The implementation of accountability has in principle been carried out in stages within the government. Support for regulations that are directly related to the necessity of implementing accountability in every government agency shows the seriousness of the government in efforts to reform the bureaucracy [7].

\section{METHOD}

This type of research is descriptive. Research data in the form of primary data. The research instrument is in the form of a questionnaire. The research population is all employees of the Regional Financial and Asset Management Agency of Batu Bara Regency. The research sample is 35 people. The sampling technique is non-probability sampling with the census method, which is a sampling method where the entire population is used as a sample [9]. The research data were analysed using a simple regression model which was preceded by prerequisite tests in the form of linearity and normality tests and $\mathrm{t}$ test.

\section{RESULT AND DISCUSSION}

The results provide empirical evidence that if the Financial Report on Performance Accountability refers and optimizes it on the theory of [1], [4] and [8], then the financial report on the accountability of employee performance at the Batu Bara Regency Education Office will be better. This refers to statistical analysis which includes: product moment coefficient analysis, coefficient of determination, simple linear regression, and calculation of hypothesis testing. Then after the results are known, it can be explained as follows:

The results of the product moment correlation explain that there is a "sufficient" influence between Financial 
Reports on Performance Accountability at the Batu Bara Regency Education Office with a percentage of 0.524 . This opinion refers to Guilford's opinion if the calculation result of 0.40-0.60 is declared "Enough"

The results of the correlation of determination explain the relationship between Financial Statements and Performance Accountability at the Education Office of Batu Bara Regency with a result of $27.4 \%$ in the "Low" category. This means that in the correlation test of determination there is an influence of $27.4 \%$ between the Financial Statements and $85.1 \%$ is influenced by other factors.

Then with the results of a simple linear regression with the formula $Y=a+b X$ with the results $a=15.626$ and $\mathrm{b}=0.475$, the regression equation $\hat{Y}=15.626+0.475$ $(X)$ can be used to predict how individuals from the dependent variable will occur when the individual in the variable is set.

Then the results of hypothesis testing with the t-count formula stated that the Financial Statements on Performance Accountability at the Batu Bara Regency Education Office are significant with 6.088 because tcount $6.088>\mathrm{t}$ table 2.040 then the results is "significant", with the conclusion because the $\mathrm{t}$-count $>\mathrm{t}$ table, it can be said that $\mathrm{HO}$ is rejected, meaning that with an error probability of 0.05 or $5 \%$, it can be concluded that the alternative hypothesis $\mathrm{Ha}$ is accepted, which means that the alternative hypothesis "The Effect of Financial Statements on Performance Accountability at the Education Office of Batu Bara Regency" is tested and acceptable.

By results of the calculations above, it shows that the Financial Report on Performance Accountability at the Batu Bara Regency Education Office, it is in accordance with the results of interviews with various related to this research, be it the separate apparatus such as office employees at the Batu Bara Regency Education Office, employees of the Regency Education Office. Batu Bara, the Head of Sub-Division of the Education Office of Batu Bara Regency, they described that the Financial Report has been running but the results and efforts made have not been optimal and there are still budget funds that are late from the central government.

\section{CONCLUSION}

Based on the results of the research that the author did regarding the influence of financial statements on performance accountability at the Batu Bara District Education Office, the conclusions that the authors present are as follows:

a. The magnitude of the effect of the Dimensional Balance on Performance Accountability at the Education Office of Batu Bara Regency is $78 \%$. With the provision that $\mathrm{r}$ arithmetic is greater than $r$ table $(0.8890 .355)$ with the hypothesis $(6.088$
0.040) which means that there is a significant effect.

b. The magnitude of the effect of the dimensions of the Cash Flow Statement on Performance Accountability at the Education Office of Batu Bara Regency is $73 \%$. With the provision that $r$ arithmetic is greater than the table (0.889 0.355) with the hypothesis (6.088 2.040) which means that there is a significant effect.

c. The magnitude of the effect of the dimensions of the Report on Financial Statements on Performance Accountability at the Education Office of Batu Bara Regency is 78\%. With the provision that $\mathrm{r}$ arithmetic is greater than the table (0.889 0.355$)$ with the hypothesis (6.088 2.040) which means that there is a significant effect.

By results of the calculations above, it shows that the Financial Report on Performance Accountability at the Batu Bara Regency Education Office, it is in accordance with the results of interviews with various related to this research, be it the separate apparatus such as office employees at the Batu Bara Regency Education Office, employees of the Regency Education Office. Batu Bara, the Head of Sub-Division of the Education Office of Batu Bara Regency, they described that the Financial Report has been running but the results and efforts made have not been optimal and there are still budget funds that are late from the central government. Therefore, [10] states in his research that analysing of budgeting is still rare.

\section{REFERENCES}

[1] Mahmudi. (2016). Analisis Laporan Keuangan Pemerintah Daerah. Yogyakarta: Sekolah Tinggi Ilmu Manajemen YKPN

[2] DO Sihotang (2020). PRINCIPLES OF EDUCATION FINANCING, Bunga Rampai EKONOMI DAN PEMBIAYAAN PENDIDIKAN. Zifatama Zawara: Sidoarjo

[3] Osadchy, E. A., et al. (2018). Financial statements of a company as an information base for decisionmaking in a transforming economy. European Research Studies Journal, 21(2), 339-350. https://doi.org/10.35808/ersj/1006

[4] Mardiasmo. (2002). Akuntansi Sektor Publik. Yogyakarta: Andi

[5] Angela, W., \& Aryancana, R. (2017). The Effect of Financial Reporting Quality on Financing and Investment. Etikonomi, 16(1), 81-92. https://doi.org/10.15408/etk.v16i1.4600

[6] Welly, Y., et al. (2021). INTERNATIONAL JOURNAL OF TRENDS IN ACCOUNTING RESEARCH The Effect of Capital Employed, 
Human Capital And Structural Capital on Financial Performance on The Consumer Goods Sector Period 2015-2019. / International Journal of Trends in Accounting Research, 2(1), 2021. https://journal.adaindonesia.or.id/index.php/ijtar/in dex

[7] G. Rasul, Syahrudin. (2003). Pengintegrasian Sistem Akuntabilitas Kinerja dan Anggaran dalam Perspektif UU No. 17/2003 Tentang Keuangan Negara. Jakarta:PNRI

[8] Gong, X. and Tsang, M.C. (2011), "Interprovincial and Regional Inequity in the Financing of Compulsory Education in China", Emerald Group Publishing Limited, Bingley, pp. 43-78. https://doi.org/10.1108/S14793679(2011)0000015006

[9] Sugiyono. (2017). Metode Penelitian Kuantitatif, Kualitatif, dan R\&D. Bandung: CV.Alfabeta

[10] Sihotang, D. O., Sianturi, E., Sitorus, I., Daryanto, E., Kunci, K., Rencana, A., \& Swot, A. (2018). Analisis Perencanaan Strategis di SMP Swasta Arina Sidikalang. EducanduM, 11(2), 27-39. 